\title{
Research on Transparency Reform of International Commercial Arbitration
}

\author{
Haojun Zhong \\ Economic and Trade Department, Fuzhou University of International Studies and Trade, Changle, 350202, \\ China
}

Keywords: Transparency reform, International commercial arbitration, International investment arbitration.

\begin{abstract}
International commercial arbitration has always been adhering to the confidentiality principle. However, the arbitration transparency issues are increasingly attracting more and more attention in the international investment dispute arbitrations. This paper expounds the advantages and feasibility of the transparency reform of international commercial arbitrations, and carries on the analysis from the perspectives of the transparency reform before, during and after arbitral proceedings to provide some references for the relative researchers.
\end{abstract}

\section{Introduction}

International commercial arbitration means arbitration to resolve disputes in international business activities. International business disputes are the disputes arising from the differences among the parties in the process of overseas business. It includes the business between different countries because of the direct business activities arising from the controversy, or the business between different countries for private overseas and business activities causing controversy and foreign commerce. The object of international business arbitration is the dispute between foreign businessmen and the host government. International commercial arbitration has its own characteristics. It differs from commercial arbitration. The status of the state in international business is different from that in civil activities. In international business, the relationship between the state and the business is more managed and managed. On the issue of the status of the state and the business people, Chinese scholars generally believe that the legal status of the two sides is different. The rule of transparency has been transferred from the domestic law to the field of international law. However, there is no uniform definition in the world in terms of the content of the international commercial arbitration mechanism and the content of the business agreements of various countries. But have not yet been defined in the universal application of transparency in international commercial arbitration rules, according to its past and present text, one aspect of information disclosure transparency rules involving at least the public information and commerce national arbitration proceedings or the program itself. From the aspect of international commercial arbitration, the transparency rule is the procedural stipulation of the information disclosure between the business person and the country. The rules of transparency play an important role in business dispute resolution and even the whole international business law.

\section{Benefits of Transparency Reform of International Commercial Arbitration}

The transparency reform of international commercial arbitration can enhance the international investment arbitration transparency, which helps maintain the public interests of host countries. Most of international investment disputes are closely related to environmental protection, health protection, sustainable development and other public interests. The transparency requirements include the first to announce to the public the dispute has entered the arbitration procedure, so that the relevant parties and the case of the interested points can understand the reasons and the dispute, to collect evidence so that they will be more targeted, more profit on their own. Moreover, the opinions of the court friends 
submitted by some professional and authoritative third parties have great influence on the public opinion in the society, which can arouse the attention of the arbitration tribunal to the public interest. Before introducing the concept of transparency in the procedure of international investment disputes arbitration, the procedure of investment arbitration is as secret as that of commercial arbitration. Only the two parties involved in the arbitration, the lawyers and arbitrators, have a detailed understanding of the arbitration cases. After the arbitration begins, both parties may compromise with each other to settle the dispute in the most economical and swift way. Transparency in international commercial arbitration can enhance the transparency of international investment arbitration and help to improve the quality of arbitration. Although the host country holds a rich economic and political resources, but the country cannot grasp the specific matters relating to the arbitration of disputes in all aspects, such as environmental protection, human rights and public welfare, it is difficult to collect relevant evidence. Moreover, the government of the host country is likely to lack the expertise needed to conduct investment arbitration. In the investment arbitration rules, the selection of the arbitrators has strict requirements for their qualifications. But it does not guarantee that all points of the arbitrator can grasp all the points of the case to complete the ability of arbitration.

\section{Feasibility of Transparency Reform of International Commercial Arbitration}

The arbitration institution is the leader of the whole arbitration system and the initiator of transparency reform. To attract more potential customers and increase market share, the arbitration body revised the arbitration rules, including the publication of certain procedural details to enhance the accuracy of the arbitral award. The more and more new demands detailed code of ethics and enhance the transparency of the review process, to gray limits the discretion of the arbitrator, indicates that another important progress in quality decision process mechanism and honest commitment to transparency reform is a new handbook of international lawyers' association published the handbook, the type of arbitration librarians must disclose information. These practices have directly promoted the code of conduct of arbitrators and the procedures of arbitral bodies to become more transparent.

To enhance the credibility and predictability of arbitration and to use more precise arbitration rules, new institutions need to do the same with new arbitrators. The concept of fuzzy arbitrator can only with the legitimacy of the feeling and the use of equity to settle a lawsuit, the new generation of arbitrators has no master level professional qualifications or status. Instead, they have adopted a more professional approach to arbitration decisions. This meticulous professional practice just to meet the needs of the parties, the drafting of the contract parties because now more and more complicated situation specific, all attempts to exhaustion may happen in the future, I hope the final contract signed between the parties is the law can be enforced. Thus, in view of this competitive situation, the previously opaque, compromise arbitration has largely been replaced by more precise explanations of the reasons.

The lawyers and arbitrators involved in the arbitration case may come from different legal systems, and the game among them will increase the predictability and standardization of the debate procedure and the collection of evidence. The collection of evidence, cross examination and debate program is vulnerable to outside influence, may be to adapt to the case the arbitrators and the parties continue to adjust personal preferences. Today, with the increasing number of arbitrators of the new generation, the international arbitration procedures and rules are developing fast in a unified and standardized model.

\section{Path Exploration of Transparency Reform of International Commercial Arbitration}

Transparency before Arbitral Proceedings.In the open platform, a unified information database of international arbitrators is established to facilitate the understanding of arbitrators' experience and professional knowledge. In addition, the current prevailing international practice is the arbitration proceedings before the start of the arbitrators and the parties can interview, so you can determine whether each schedule or conditions in accordance with the requirements of the professional, 
convenient replacement of the arbitrator to hear. The practice of selecting arbitrators has now become obsolete, contrary to the original intention of transparency. Today, the modernization of information technology is both expensive and inefficient. It is not in line with the development and needs of modern society. Empirical research shows that the parties agree to choose arbitration as a way of dealing with disputes, largely because they can choose arbitrators themselves. International arbitration institutions and domestic arbitration institutions may establish a unified database of international arbitrators. It makes the detailed introduction of the arbitrators and the qualification resume charging standard. The architecture of a one-stop shopping model provides a reliable source of information. In China, arbitration institution for arbitration, if the parties agree to form an arbitration tribunal composed of three people, the parties refer to any arbitrator respectively, then any common name the chief arbitrator in view of the problems such as conflicts of interest, the chief arbitrator appointed both difficult to reach agreement, usually appointed by the arbitration commission on behalf of the two sides. The parties may understand the relevant information of the arbitrators, through the introduction of active consulting, website information or other channels, if you have interest in one arbitrator, privately cannot go directly to the arbitrator communication. Now the popular approach is the arbitrator and the parties can interview before the commencement of arbitration proceedings to determine whether the time schedule and qualifications are in accordance with the trial of the case.

Transparency during Arbitral Proceedings. At present, although the confidentiality is the basic attribute of international arbitration, the international arbitration cases are involved with more and more public concern, such as environmental pollution, the exploitation of workers and the exploitation of child company crime. All these problems need the information disclosure in the arbitration procedure to supervise the whole case effectively. But in the information disclosure, we should prevent too broad, strictly define the public interests, limit the scope of public interests, and cannot completely abandon the confidentiality of arbitration. If the information involves the fairness of the case, or involves the interests of the unilateral party, information disclosure can be carried out, and in addition, if the information has been disclosed in the arbitration process, the protection will be very low. Mandatory disclosure of financial information by companies and securities laws in various countries has also become an important source of information for international arbitration cases. In fact, the original intention of designing information disclosure obligations is to help investors make decisions. According to the current company and company law framework, the information disclosure rules are vague and easily manipulated by the management. When there is an abuse of power within the company, the interest in management may not be consistent with the public interest. These human factors are not inherent in the disclosure mechanism, so new disclosure standards need to be designed. If the new disclosure standards are more detailed and specific adjustment, not only helps to meet the information needs of relevant investors, but also to meet the needs of other public interest information. If the company advocates only that it has undertaken corporate social responsibility and has not disclosed any negative information, it can be regarded as a securities fraud. More and more parties are now turning to domestic courts for evidence, temporary relief, and enforcement decisions. This practice leads to information about arbitration cases being made public. But because of differences in the legal system, not the world judicial procedure can provide the same level of disclosure, such as some state law does not stipulate that the arbitral award should be implemented, and in some countries the enforcement of the arbitral award is the condition of public verdict reason. This is not to promote transparency in the international commercial arbitration system, but in fact to improve the transparency and legitimacy of the judicial process of the court. If the citizens want to get in the arbitration proceedings of the information and evidence for the court proceedings, can request to the court, the court shall request, administrative agencies can command arbitration institutions of information disclosure. For example, the British international arbitration award and the document is confidential information, to be invoked in the arbitration proceedings. But, if the information involves fairness in the trial of the case, or involves the interests of the unilateral party, we will disclose the information. 
Transparency before Arbitral Proceedings. It is necessary to open an arbitral award to achieve the breakthrough reform of arbitration transparency, either by the party himself or by the arbitral tribunal. Among them, the American Arbitration Association stipulates that the arbitral tribunal must specify the reasons and the basis for the award when the award is made. If required by law, public judgment should be made. The arbitration award shall also be reported, filed and registered in accordance with the requirements of the domestic law. Unless the parties disagree, the arbitral tribunal may disclose the names of the parties and other identity information of the arbitral award. With the practice of arbitration institutions open arbitration decisions more and more practice, international arbitration has become increasingly transparent and benign mechanism. In addition, if the domestic judicial assistance procedure or judicial arbitration procedure is required to be made public, then the arbitration institution will also announce it to the public. The active public arbitration award is a breakthrough in transparency reform. Whether it is the party's own open verdict or the arbitration institution's open verdict, it will be of great benefit to both academic research and arbitration practice. We can learn from the practice of international arbitration rules: the reasons and basis of the arbitration tribunal must be listed in the ruling of the ruling; if there are legal requirements should open arbitration award; the need for archiving and reporting level according to domestic law requirements; unless the parties do not agree, the arbitration institution can be published or otherwise available to the public edited to anonymous or other details, or during the execution of the public or other means of public decision and ruling. With the increasing number of public arbitration institutions, the international arbitration circle will gradually form a more transparent and benign mechanism. If the arbitrators invoked these published decisions when they tried the case, the published verdict would be judged. The award shall be made public at the request of the domestic company law, securities law, judicial assistance procedure or judicial proceedings, and the arbitration institution shall also announce the content of the award.

\section{Conclusion}

Transparency is an inherent characteristic of the rule of law. Public voices and government involvement have also become catalysts to accelerate the transparency reform. Therefore, the international arbitration community should take the initiatives to carry out the transparency reform and to increase the transparency in the process of competition and cooperation among the arbitration institutions. It not only protects the rights and interests of foreign investors, but also protects China's national interests.

\section{References}

[1] He Qisheng. Public Policy in the Judicial Review of International Commercial Arbitration [J]. Social Sciences in China, 2014(7): 143-163+207-208.

[2] Lin Qimin. Transparency in International Commercial Arbitration [J]. Hebei Law Science, 2015, 33(6): 113-123.

[3] Zhao Jun, Liu Yun. The Transparency Reform in International InvestmentArbitrationandChina's Reactions [J].J ournal of Zhejiang University (Humanities and Social Sciences), 2014, 44(3): 150-163.

[4] Zhang Jian. International Challenges of China's Commercial Arbitration From the Perspective of Judgement View of Supreme People's Court [J]. Journal of Taiyuan University of Technology (Social Science Edition), 2015, 33(5): 13-18. 